PART III

UNCOVERING ALMOHAD IBERIA 


\title{
EVOLUTION OF THE ANDALUSI URBAN LANDSCAPE: FROM THE DISPERSED TO THE SATURATED MEDINA
}

\author{
Fulio Navarro and Pedro Fiménez*
}

If we review the historiography on Islamic urbanism, one of the fundamental issues from the pioneering studies to the contemporary critic has been the supposedly static character of the medina, an issue which has also been raised in recent critical discussions regarding the relevance of the notion of the timeless Islamic city. ${ }^{1}$ Today, almost all scholars accept that the medina is not an immutable entity and that it is untenable to argue that in the medieval period the medina was like the traditional examples which have survived to the twentieth century. Nevertheless, no doubt due to the difficulty of gathering relevant data, an explanation of the original character of these medinas and the processes by which they evolved into the archetype described by early Orientalist scholars has yet to appear. ${ }^{2}$

Most scholars accept that Islamic cities did not originally resemble those of the nineteenth century, and that they were not constructed with disordered cores, dead-end alleys, and quarters, which are supposedly characteristic of the Islamic city. We felt the subject needed to move forward, and we wanted to answer questions such as "What were the first cities founded by Muslims like? How did they evolve over time, up to the point at which they took on the appearance described by earlier scholars?". We therefore published in 2003 a comprehensive article entitled "Sobre la Ciudad Islámica y su Evolución", and in the following year a summary called "Evolución del Paisaje Urbano Andalusí: de la

\footnotetext{
* Translated by Glaire D. Anderson.

1 See Robert Ilbert, "La ville islamique: réalité et abstraction", Les Cahiers de la Recherche Architecturale 10-11 (1982), pp. 6-13; Janet L. Abu-Lughod, "The Islamic City: Historic Myth, Islamic Essence and Contemporary Relevance", International Fournal of Middle East Studies 19 (1987), pp. 155-177; André Raymond, "Ville musulmane, ville arabe: mythes orientalistes et recherches récentes", in Panoramas Urbains: Situation de l'Histoire des Villes, ed. Jean-Louis Biget and Jean-Claude Hervé (Fontenay-aux-Roses: Presses de l'ENS, 1995), pp. 309-336.

2 See Abu-Lughod, "The Islamic City".
} 
Medina Dispersa a la Saturada", ${ }^{3}$ in which we tried to determine the principals which governed the processes of urban transformation over time, which García-Bellido has defined as the "morphogenetic rules". The principles which we deduced are very general and can be applied to settlements of different time periods and different cultures, so long as we keep in mind the specific historical and physical factors which determined the development of each city. Nevertheless, we believe that the resulting model, summarized in this article, can be useful in understanding the evolution of medieval medinas (Fig. 1). We have based our model on three sources: archaeological information, in particular from two exceptional sites which we have excavated ourselves, Siyāsa and Murcia; on ethnoarchaeological studies; ${ }^{4}$ and on written sources, especially the Arabic texts.

\section{Constitution}

In the medieval period, the construction of city walls was the culmination of the first, or constitutive, stage. This phase is characterized by the existence of wide, unbuilt intramural zones intended for use as orchards and gardens. Also forming part of the intramural zone of the city in its earliest phase are phenomena traditionally designated as periurban: cemeteries, pottery kilns, tanneries, etc. These elements form the subject of the following sections.

\subsection{Foundation Walls}

Almost always present in the medieval city, the construction of the first walls is one of the milestones of the medina's formative period. Apart from defensive and topographical considerations, their route was planned and conditioned in order to enclose large empty zones,

\footnotetext{
${ }^{3}$ This is an adapted translation of that second article, see Julio Navarro Palazón and Pedro Jiménez Castillo, "Evolución del Paisaje Urbano Andalusí: de la Medina Dispersa a la Saturada", in Fátima Roldán Castro ed., Paisaje y naturaleza en al-Andalus (Granada: El Legado Andalusí, 2003), pp. 232-267.

${ }^{4}$ Ethnoarchaeology is the study of a society's institutions based on examination of its material attributes. See Michèle Biewers, "Occupation de l'espace dans le village traditionnel de 'Aima: approche etnoarchéologique", Studies in the History and Archaeology of Fordan IV (Amman, Department of Antiquities, 1992) pp. 397-402; Olivier Aurenche, "Pour une éthnoarchéologie des cycles d'évolution dans l'habitat rural du Proche-Orient", Studies in the History and Archaeology of Fordan V (Amman, Department of Antiquities, 1995), pp. 307-319.
} 


\section{EVOLUTION OF THE ISLAMIC CITY}

\section{TRADITIONAL PATTERN}

NEW PROPOSAL
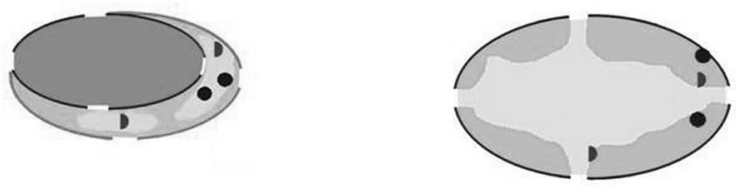

CONSTITUTION OF THE MADINA
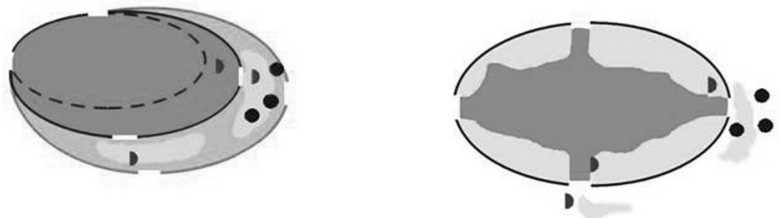

$2^{a}$

EXPANSION
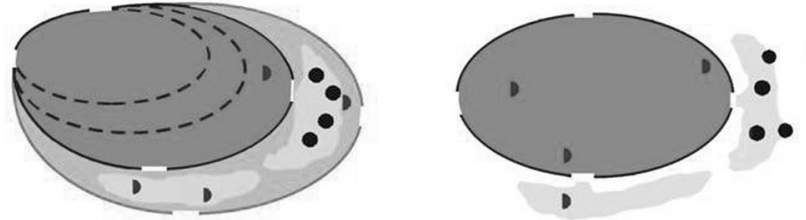

$3^{a}$

SATURATION
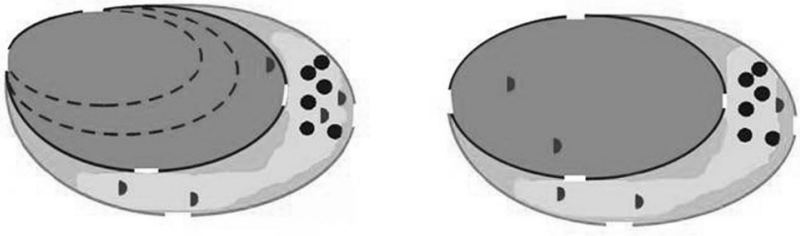
$4^{a}$
OUTBREAK
$1^{a}$

CONSTITUTION O THE OUTSKIRTS

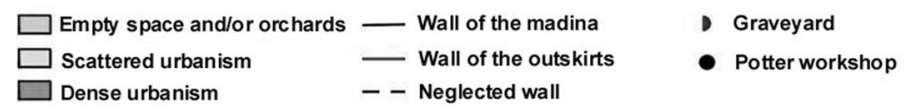

Fig. 1. Evolution of the Islamic city. 
especially in the periphery of the inhabited nucleus. Lézine based his demographic calculations of medieval Islamic cities upon the area of mosques and comparisons with the extension of an individual city's walled perimeters. Lézine did not link the expansion of the walled centre to any foresight on the part of medieval architects, but rather to the "galloping demography" of the times. ${ }^{5}$ However, Lézine's model does not adequately recognize planning foresight in the early phase of a city's urban development. In contrast, we would argue that the empty spaces which, like a belt, sit between the town and the walls can only be understood as reserved areas destined for later development, as the city's growth required. Therefore, an understanding of city walls constructed to protect the earliest Andalusi cities can illuminate formative urban processes, when examined in conjunction with written sources and archaeological evidence.

Understanding the routes of early Islamic urban walls is at present central to the study of urbanism, offering a corrective to tendencies which establish the extension and characteristics of medieval cities as based on unfounded and a priori conjecture: for example, the tendency to always characterize orchards, potteries and cemeteries as periurban phenomena. On the contrary, medieval walls constructed in the early phase of a medieval city's urban development delimited a dispersed urban landscape in which ample productive agricultural land was found alongside artisanal and commercial areas and cemeteries. In this early stage the city was not saturated, and therefore had no need to expel to its margins that which at later stages can be understood as periurban phenomena.

\subsection{Empty spaces within the walls}

Another stereotype with a long historiographical tradition is that of the notion of a contrast between medieval Christian and medieval Islamic cities: the former are viewed as spaces in which towns and unbuilt areas lived in harmony, while the latter are usually associated with an urban fabric in which unbuilt zones are scarce or do not exist at all. Lézine was among the first to criticize this idea, noting that just two or three centuries ago, descriptions indicate that pre-modern Islamic cities included open spaces, public squares, gardens and orchards, which have

${ }^{5}$ Alexandre Lézine, Deux villes d'Ifriqiya (Paris: P. Geuthner, 1971), p. 20. 
subsequently disappeared; medieval Islamic urbanism was therefore much more "airy" than the well-known case studies may have appeared in the nineteenth century. ${ }^{6}$ Certainly, textual evidence indicates that the presence of orchards and gardens within the pre-modern Islamic city was considered a sign of health and quality of life, while their absence denoted congestion and unhealthiness. ${ }^{7}$ Some who identified the existence of such spaces in the Islamic city suggested that their presence could be explained for military reasons, understanding the orchards as destined to secure the provisioning of food for the city in the event of a siege. ${ }^{8}$ Others interpreted them as symptoms of urban decline, a judgement which is only occasionally accurate. ${ }^{9}$ In our opinion, this belt of unbuilt spaces and/or orchards located between the built core and the city wall, intended to absorb the future growth of the city, is a characteristic element of the medina's formative period.

Other unbuilt spaces existed in the very heart of the city, often attached directly to adjacent residences and, in combination with the unbuilt zones at the perimeter of the town, created an urban fabric with a dispersed appearance. The deserted Jordanian site of Umm al-Jimal, the tenth-century palace city of Madinnat al-Zahrā' in Córdoba, and the cities of Siyāsa and Murcia (both prov. Murcia), provide interesting and complementary information about the dispersed nature of the Islamic city during its formative stages.

Umm al-Jimal (Fig. 2) is a rare example of a dispersed city which was abandoned before its conversion into a so-called traditional city. It has therefore been preserved at an early stage of street formation, when large, open spaces still predominated in the urban fabric. ${ }^{10}$ In the plans, one can clearly make out city blocks and the large houses

\footnotetext{
${ }^{6}$ Lézine, Deux villes, pp. 124-125.

7 S. D. Goitein, A Mediterranean Society. The Jewish communities of the Arab world as portrayed in the documents of the Cairo Geniza. Vol. IV: Daily life (Berkeley-Los AngelesLondon: University of California Press, 1983), p. 47.

${ }^{8}$ Hamid Triki, "Marrakech: retrato histórico de una metrópoli medieval. Siglos XI-XII", in La Arquitectura del Islam Occidental, edited by Rafael López Guzmán (Granada: El Legado Andalusí, 1995), pp. 93-106.

9 This is the case at Samarra, Kufa and Basra in the eleventh century: see Thierry Bianquis, "Derrière qui prieras-tu, vendredi? Réflexions sur les espaces publics et privés, dans la ville arabe médiévale", Bulletin d'Études Orientales XXXVII-XXXVIII (1985-1986), pp. 7-21.

${ }^{10}$ Bert De Vries, "Urbanization in the Basalt Region of North Jordan in Late Antiquity: the case of Umm al-Jimal", Studies in the History and Archaeology of Fordan II (Amman-London: Department of Antiquities, 1985), pp. 249-256.
} 


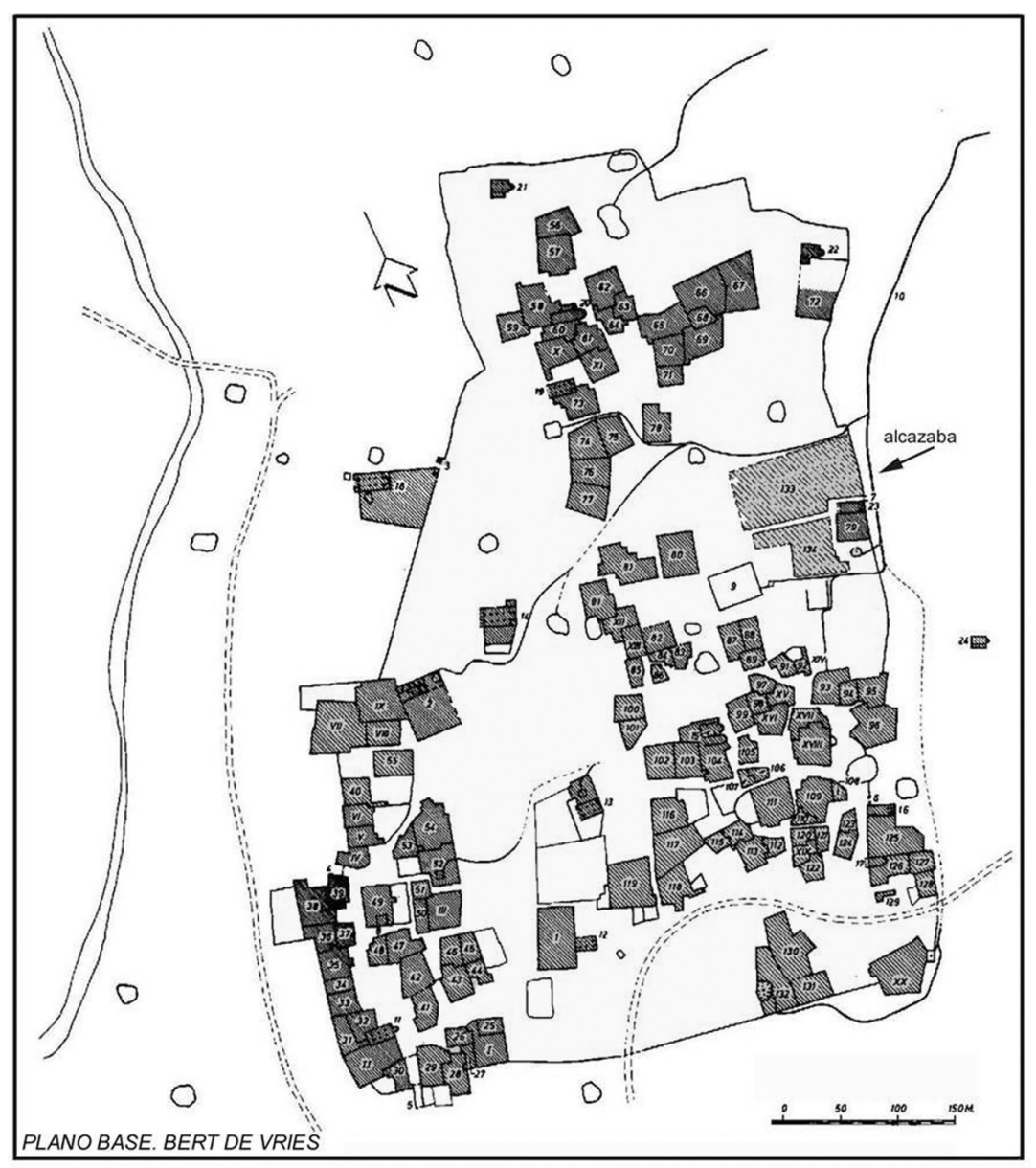

Fig. 2. Umm al-Jimal (Jordan). Byzantine site abandoned in the Umayyad period. Note the large empty spaces, and the streets in the process of formation in the areas where the town increases in density. 


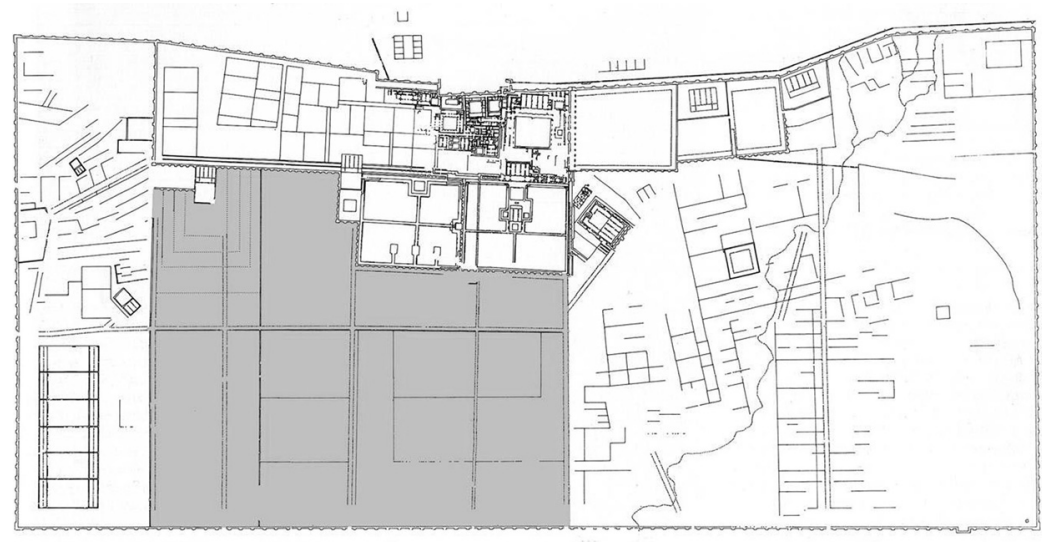

PLANO BASE. PLAN ESPECIAL DE MADINATAL-ZAHRA

Fig. 3. Madīnat al-Zahrā' (Córdoba, tenth century). Highlighted area indicates zone likely used for cultivation in the form of orchards.

which developed by joining together domestic units, when excess space still existed within the walled enclosure.

In contrast, Madīnat al-Zahrā' (Fig. 3) presents a geometric organization, but it also illustrates the appearance of a city before the advent of the later phases of saturation and overflow. In the plan published by Vallejo, wide interior zones free from construction, and of uncertain function, are clearly visible, preserved at their formative stage because of the early destruction of the city. ${ }^{11}$ Traces of the regular organization characteristic of irrigated lands are visible in the large space situated in the centre of the city, suggesting that this zone was intended for use as cultivated land, probably, in fact, as orchards.

In addition to extensive land reserves between the town and the walls, the first family groups to settle within the city of Murcia provided for ample free space between houses (Fig. 4). No material evidence exists for the function of these spaces, though it is logical to suppose that they were associated with the families who resided in close proximity to the plots, and that they may have been used as orchards or gardens. Al-Maqqarī supports this picture of early Murcia when he notes it was "called al-Bustān (the Garden/Orchard) for its numerous enclosed

${ }^{11}$ Antonio Vallejo Triano, "El proyecto urbanístico del Estado califal: Madīnat alZahrā'”, in La Arquitectura del Islam Occidental, pp. 69-81. See also Vallejo Fig. 1 in this volume, and p. 6 in his discussion. 


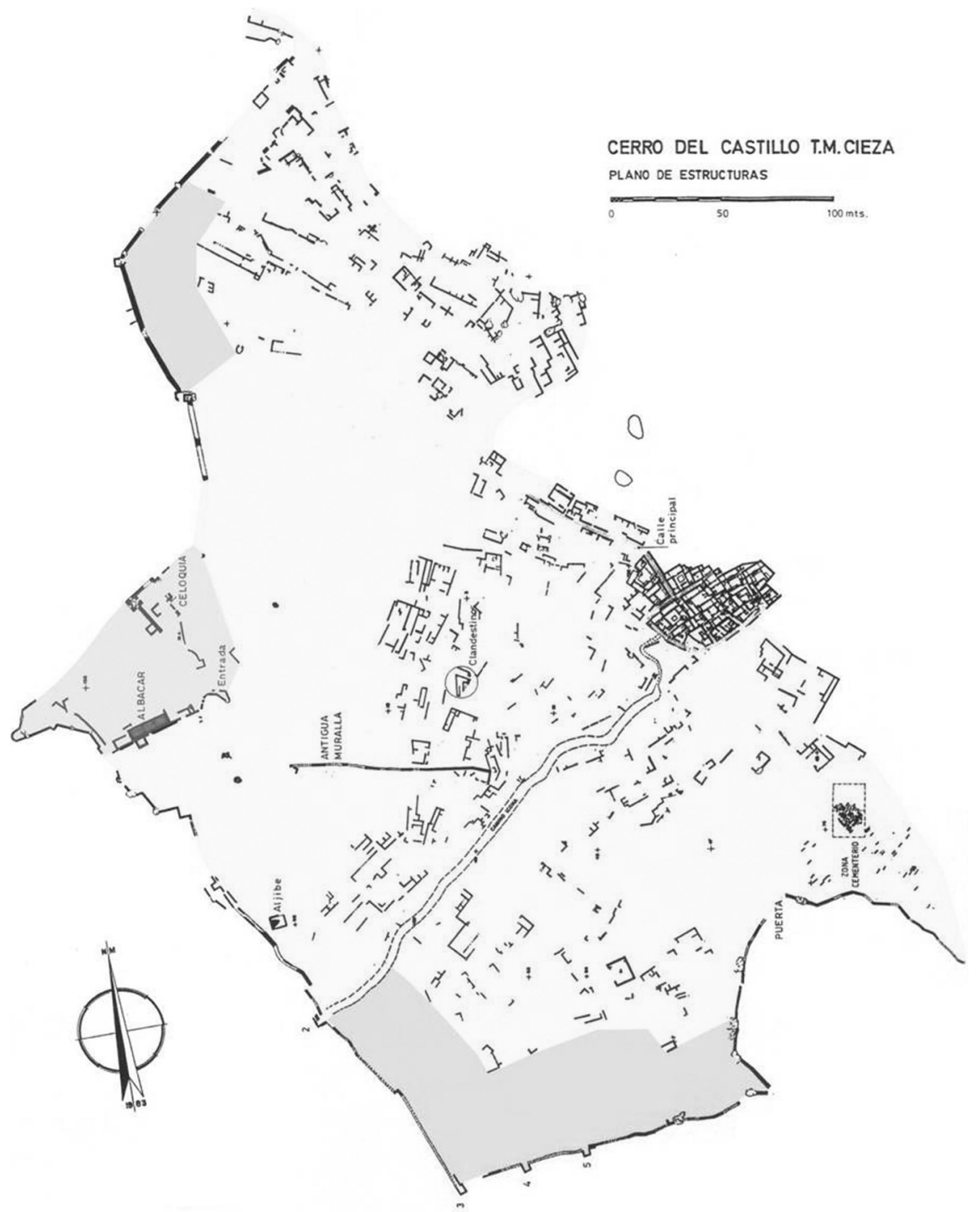

Fig. 4. Abandoned town of Siyāsa (modern Cieza, prov. Murcia, twelfththirteenth centuries). Plan of the site with visible remains and excavated area, the fortress and cemetery. The peripheral sectors between the castle and the wall, which never became urbanized, are highlighted. 
orchards". ${ }^{12}$ The orchards to which al-Maqqarī referred were not those of the famous and extensive plain of the Segura river, where cultivated plots with walls were incompatible with traditional systems of community irrigation. Rather, al-Maqqanī was describing orchards located within the city itself, and from which the city derived its name. These were eventually built upon in response to the city's population growth.

The abandoned site of Siyāsa offers another example of an ample open zone within a walled urban centre (Fig. 4). The plan of the site indicates that its southern face and the interior sectors next to the wall were free from construction, indicating that this zone was reserved for the natural growth of the community. In Siyāsa there also exist earlier empty areas between houses, which were only built up later, as we will discuss below.

\subsection{Intramural cemeteries}

Since the cemeteries of cities which survived into the nineteenth century were situated outside the city walls, they are considered one of the typically suburban elements of the pre-modern medina. As a result, historians often interpret cemeteries located within medieval city walls as exterior foundations which were incorporated into the urban enclosure by the expansion of the walls. However, a failure to distinguish between the dispersed and saturated phases of medieval cities leads to the incorrect conclusion that cemeteries were not part of the original urban nuclei. In fact, residents of medieval cities had no problem with including cemeteries within the walled urban centre.

Textual evidence again supports this assertion: for example, in Basra (founded 638), each of the Arab tribes received a territorial demarcation, or khitta, in which to establish their houses. According to al-Mawardī, at the centre of each of these five quarters, which surrounded the congregational mosque and the Dār al-Imāra, a wide open space (raḥba) was reserved to serve as stabling for horses, for prayer, and as a cemetery. ${ }^{13}$ Likewise, in each khitta of the twenty which made up Kufa, founded

\footnotetext{
12 Alfonso Carmona González, "Murcia ¿Una fundación árabe? (Nuevos datos y conclusiones)", in Murcia Musulmana, ed. Francisco J. Flores Arroyuelo et al. (Murcia: Ediciones Almudí, 1989), pp. 85-147.

${ }^{13}$ Jamel Akbar, Crisis in the Built Environment: the Case of the Muslim City (Singapore: Concept Media Pte Ltd., 1988), p. 86; see also Nezar Alsayyad, Cities and Caliphs: On the Genesis of Arab Muslim Urbanism (Wesport: Greenwood, 1991), pp. 51-53.
} 


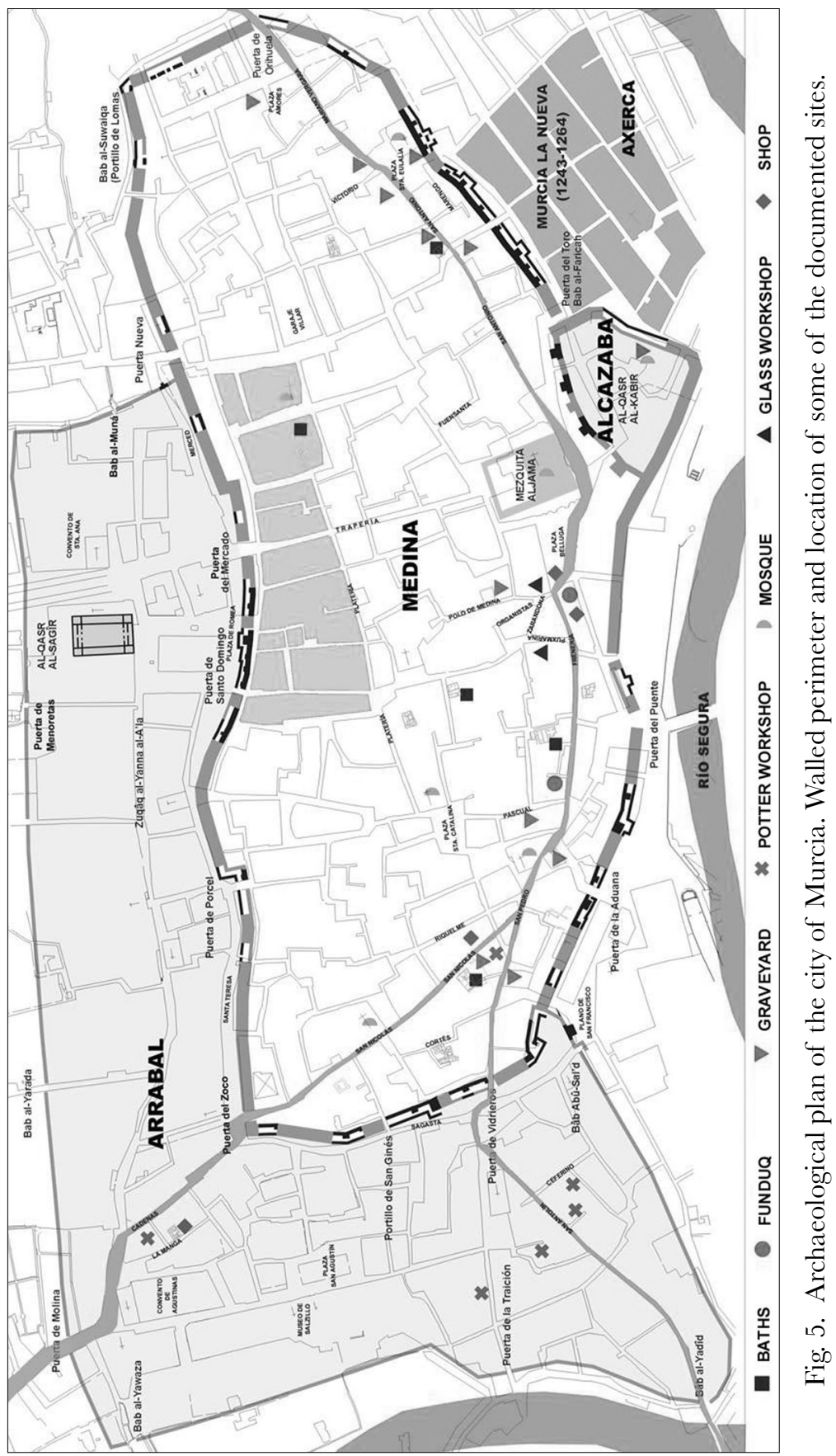


about the same time as Basra, the tribes established their own mosque and their own place of burial. ${ }^{14}$

In Murcia, cemeteries were not only sited within the walls, but were founded at an early period within pre-existing structures, normally houses (Fig. 5). ${ }^{15}$ This phenomenon constitutes eloquent proof that in the dispersed city the presence of intramural burial sites is not exceptional. Perhaps the most paradigmatic case is that of San Nicolás (Murcia) which, in the second half of the tenth century, was occupied by a pottery workshop. A large house was subsequently constructed on the site of the pottery workshop, which in turn was transformed into a cemetery, a function which the site maintained until the conquest. ${ }^{16}$ Other examples of this phenomenon exist, most notably one located in the heart of the city on the street known as Polo de Medina, once a sumptuous residence of the caliphal period which, in the eleventh century, had a cemetery installed within it. Again, it retained this function to the end of the twelfth or beginning of the thirteenth century. ${ }^{17}$

The city of Denia provides another interesting case, in which the cemetery was located not only within the walls, but adjacent to the main city gate, and opening onto the main street. With the passage of time and the pressing need for space, the tombs eventually encroached into the street. ${ }^{18}$ Other examples exist in Orihuela, Balaguer, Valencia and Alicante. ${ }^{19}$ In Pechina, the town and cemetery are separated by a single street, but due to the usual assumption that the cemetery was always situated outside the walls, the burials were interpreted as a progressive

\footnotetext{
${ }^{14}$ Akbar, Crisis in the Built Environment, p. 88.

${ }^{15}$ Pedro Jiménez Castillo and Julio Navarro Palazón, "Génesis y evolución urbana de Murcia en la Edad Media”, in Murcia ayer y hoy (Murcia: Ayuntamiento de Murcia, 2000), pp. 40-130, especially pp. 92-94.

${ }^{16}$ Julio Navarro Palazón, "El cementerio islámico de San Nicolás de Murcia. Memoria Preliminar", in Actas del I Congreso de Arqueología Medieval Española, vol. IV (Zaragoza: Diputación General de Aragón, 1986), pp. 7-37.

${ }_{17}$ Indalecio Pozo Martínez, "El cementerio islámico de la calle Polo de Medina (Murcia)", in Actas del III Congreso de Arqueología Medieval Española (Oviedo: Universidad de Oviedo, 1992), pp. 413-421.

${ }^{18}$ Josep A. Gisbert, "Dāniya y la vila de Denia. En torno al urbanismo de una ciudad medieval", in Urbanismo medieval del País Valenciano, ed. R. Azuar et al. (Madrid: Polifemo, 1993), pp. 63-103.

${ }^{19}$ Josep Giralt Balagueró, "Balaguer", in Catalunya Romànica, vol. XVII (Barcelona: Enciclopèdia Catalana, 1994), pp. 219-251; Rafael González Villaescusa, "El barrio del Carmen de Valencia: análisis morfológico e historia urbana", Madrider Mitteilungen 41 (2000), pp. 410-435; Pablo Rosser Limiñana, "La ciudad de Alicante y la arqueología del poblamiento en época medieval islámica", in Urbanismo Medieval del País Valenciano, pp. 27-62.
} 
abandonment of the houses. The ceramic evidence, however, indicates that the houses and cemetery were actually contemporary. ${ }^{20}$

These examples demonstrate that intramural cemeteries found in saturated nuclei in al-Andalus cannot automatically be interpreted as originally extramural foundations which had been included within medieval walled centres at a later date. The fact that intramural cemeteries have been found in Murcia and elsewhere suggests that their presence was not an exclusively local phenomenon, but one that may have been a general characteristic of medieval Islamic urbanism. As a result, the value of cemeteries for measuring and dating urban development in al-Andalus needs to be redefined.

\subsection{Workshops within the walls}

Traditional historiography also considers artisanal workshops, especially pottery workshops and tanneries, to be typically periurban phenomena. Archaeological evidence and medieval texts do not support this, however, since the model that has been traditionally employed by scholars reflects a later urban reality, distinct from that of earlier periods. The following examples demonstrate that the placement of artisanal installations depends largely on the degree of saturation of the urban fabric and, finally, on the availability of space within the walled enclosure. ${ }^{21}$

In Murcia, houses as well as artisanal installations (whose products would have been sold in the adjacent market) were located behind the shops which flanked the city's principal artery. Two workshops devoted to glass production were located very near the Great Mosque, the smaller of which opened onto Plaza Belluga (Fig. 5). ${ }^{22}$ Likewise, the excavation of three sites associated with metal manufacture - specifically small forges and waste sites - indicate that in Islamic Murcia metalware and glass workers were present near the nodes of commercialization.

\footnotetext{
${ }^{20}$ Francisco Castillo Galdeano et al., "Urbanismo e industria en Bayyāna. Pechina (Almería)", in Actas del II Congreso de Arqueología Medieval Española. Vol. II. Comunicaciones (Madrid: Comunidad Autónoma, 1987), pp. 539-548.

${ }^{21}$ André Raymond, "Le déplacement des tanneries à Alep, au Caire et à Tunis à l'époque ottomane: «un indicateur» de croissance urbaine", Revue d'Histoire Maghrébine 7-8 (1977), pp. 192-200.

${ }^{22}$ Pedro Jiménez Castillo et al., "Les ateliers urbains de verriers de Murcia au XII s. (C. Puxmarina et Pl. Belluga)", in Arts du feu et productions artisanales. XX ${ }^{\text {emes }}$ Rencontres internationales d'Antibes, ed. P. Pétrequin, P. Fluzin, J. Thiriot, P. Benoit (Antibes: APDCA, 2000), pp. 433-452.
} 
Pottery workshops, dating to the tenth and eleventh centuries, were also located inside the walled centre (Fig. 5). ${ }^{23}$ Their presence has been interpreted as proof of the existence of a smaller, pre-existing perimeter wall, but this hypothesis is unfounded given the evidence we have presented for workshops, cemeteries and open spaces within the medieval city during the early dispersed phase. While pottery workshops were present within the medina walls, they tended to be located in peripheral areas, in order to avoid creating a nuisance or danger from firing the kilns.

Other examples of intramural artisanal sites include a tenth-century kiln in the medina of Alicante, and three kilns located within the fortified enclosure of the Plano de Almatá, in the old medina of Balaguer. ${ }^{24}$

The practice of locating such establishments within the city walls has been well analyzed in eastern Islamic cities such as Aleppo, where

artisanal activities which were polluting or unpleasant to the environment, such as dyeing, forging, coppersmithing and, above all, tanning, and which later would be installed in the suburbs or beyond the built zones were, at the time of the Ottoman period or even earlier, all intra muros and very close to the centre. In fact, these were essentially urban activities, and therefore integrated into the city fabric, despite their unpleasantness. ${ }^{25}$

\section{ExpANSION}

While expansion is common to nearly all cities, in the case of the medieval medinas, growth was not necessarily planned by a central authority. As Akbar has shown, the majority of Islamic nuclei expanded themselves over time under private initiative, although not at random, but in accordance with specific principles which shaped the development of the city, based on numerous small-scale decisions made by residents. ${ }^{26}$

While the term 'urban expansion' as applied to the medieval city often refers to the occupation of extramural areas, we use it here strictly in reference to the development of the walled centre at the expense of

\footnotetext{
${ }^{23}$ Navarro Palazón, "El cementerio islámico de San Nicolás".

${ }^{24}$ Rosser Limiñana, "La ciudad de Alicante", p. 43; Giralt Balagueró, "Balaguer", pp. 242-243.

${ }^{25}$ Jean-Claude David, La Suwayqat 'Al̄̄ à Alep (Damas: Publication de l'Institut Français d'Études Arabes de Damas, 1998), p. 131.

${ }^{26}$ Akbar, Crisis in the Built Environment, p. 71.
} 
orchards and/or gardens, artisanal installations and, in certain cases, empty space within the walls. Three models of expansion can be identified, based on the developed area within the medina. The first two models develop on unconstructed terrain: the first in the large open areas between the limits of the built core of the town and the wall (expansion in a strict sense), while the second consists of building over the small empty spaces which exist within the town (densification). This subdivision is somewhat arbitrary, since a clearly-defined limit does not always exist between the constructed zone and large reserved areas. It is a useful division, but it is also important to keep in mind that, from the urban-planning point of view, it is not the same to occupy and transform the spaces in small domestic orchards, and those in empty residual spaces left between older houses. In the first case, we can observe a tendency inherited from parcelling rural plots; in the second, new constructions are usually conditioned by the preexisting town. ${ }^{27}$

The third model of expansion develops on top of artisanal installations, normally tanneries and potteries, which are displaced outside the walled centre. We will discuss below the expansion over intramural cemeteries which, although rare, is another well-documented archaeological phenomenon.

\subsection{The town periphery}

This section addresses urban expansion into intramural spaces previously occupied by artisanal workshops or by cemeteries, two features of the dispersed city which, in many cases, were finally displaced outside the walled centre once the medina reached the point of saturation. This phenomenon is evident on the north side of the medina of Murcia, in the strip located between Calle Platería and the city wall (Fig. 5). This zone appears to have been occupied by orchards and gardens which effected the form of new residential blocks, whose regular appearance contrasts with those south of Calle Platería, where the oldest buildings are situated. These urban orchards, delimited by the access roads to the different plots and by the canals which irrigated them, present the regular rectilinear form characteristic of cultivated spaces. ${ }^{28}$ As these

27 These expansion phenomena can occur simultaneously, as was the case at Kufa. As new groups of settlers arrived, they chose from two solutions: if there were few inhabitants in a khitta (a plot or tribal demarcation), new arrivals might settle there; if there were already many residents, a new khitta was founded.

${ }^{28}$ González Villaescusa, "El barrio del Carmen de Valencia", pp. 65-66. 
zones were progressively built up, they maintained their pre-existing structure; had they not, one might have supposed an intervention on the part of the state.

Seville's medina probably preserves the best example of this type of regular intramural block, markedly different from those surrounding it (Fig. 6). ${ }^{29}$ It encompasses the north-western sector of the city, between the Real and Vibarragel gates. ${ }^{30}$ Sufficient evidence survives to indicate that this sector, occupied by structures surrounded by gardens and orchards, remained in an expansion phase until the conquest in 1248. ${ }^{31}$ However, we are the first to conclude that its regularity reflects the agricultural character of its initial formation. ${ }^{32}$

\subsection{Sites within the core of the medina: Densification}

The phenomenon of intramural densification is well-documented in the abandoned town of Siyāsa (Fig. 8). The best example is the enlargement of house number five, which was expanded into an empty space west of house number four. Here a second domestic nucleus was constructed, between houses twelve, four and six, whose plan reflects the difficulties of placing a building with a central courtyard in an elongated, residual site.

\footnotetext{
${ }^{29}$ A similar arrangement of city blocks is located in the Axares quarter of Granada, and in Jaén, in the area between the old gates of San Agustín and Sol: see Vicente Salvatierra and Eva Alcázar, "La distribución del agua en Jaén durante el periodo islámico", Arqueología Medieval 4 (1996), pp. 95-106.

${ }_{30}$ Part of this sector is occupied by the neighbourhood of San Vicente. Some have argued that this area postdates the 1248 conquest, while others identify it as an Almohad project. See Manuel Vera Reina, "Urbanismo medieval en la ciudad de Sevilla. El barrio de San Vicente", in Actas del II Congreso de Arqueología Medieval Española, vol. III (Madrid: Comunidad Autónoma, 1987), pp. 203-211; Manuel Acién Almansa, "La formación del tejido urbano en al-Andalus", La ciudad medieval: de la casa al tejido urbano (Cuenca: Universidad de Castilla-La Mancha, 2001), pp. 11-32.

${ }_{31}$ Documentary and archaeological evidence exists for the occupation of this zone during the Islamic period, namely the two so-called Baths of the Reina Mora and the remains of a large residential structure beneath the monastery of San Clemente. See Vera Reina, "Urbanismo medieval en la ciudad de Sevilla"; Miguel A. Tabales Rodríguez, "El edificio musulmán localizado bajo el monasterio de San Clemente", in Sevilla Almohade, ed. Magdalena Valor Piechotta and Ahmed Tahiri (Seville: Universidad de Sevilla, Junta de Andalucía, 1999), pp. 151-153.

${ }_{32}$ Without referring specifically to this zone, Almagro Gorbea, when he studied the urbanism of medieval Seville, observed that the very regular layout of the roads was due to the wide areas occupied by gardens and orchards, which were later built over: see Antonio Almagro Gorbea, "Planimetría de las ciudades hispanomusulmanas", $\mathrm{Al}$ Qantara VIII (1987), pp. 442-448.
} 


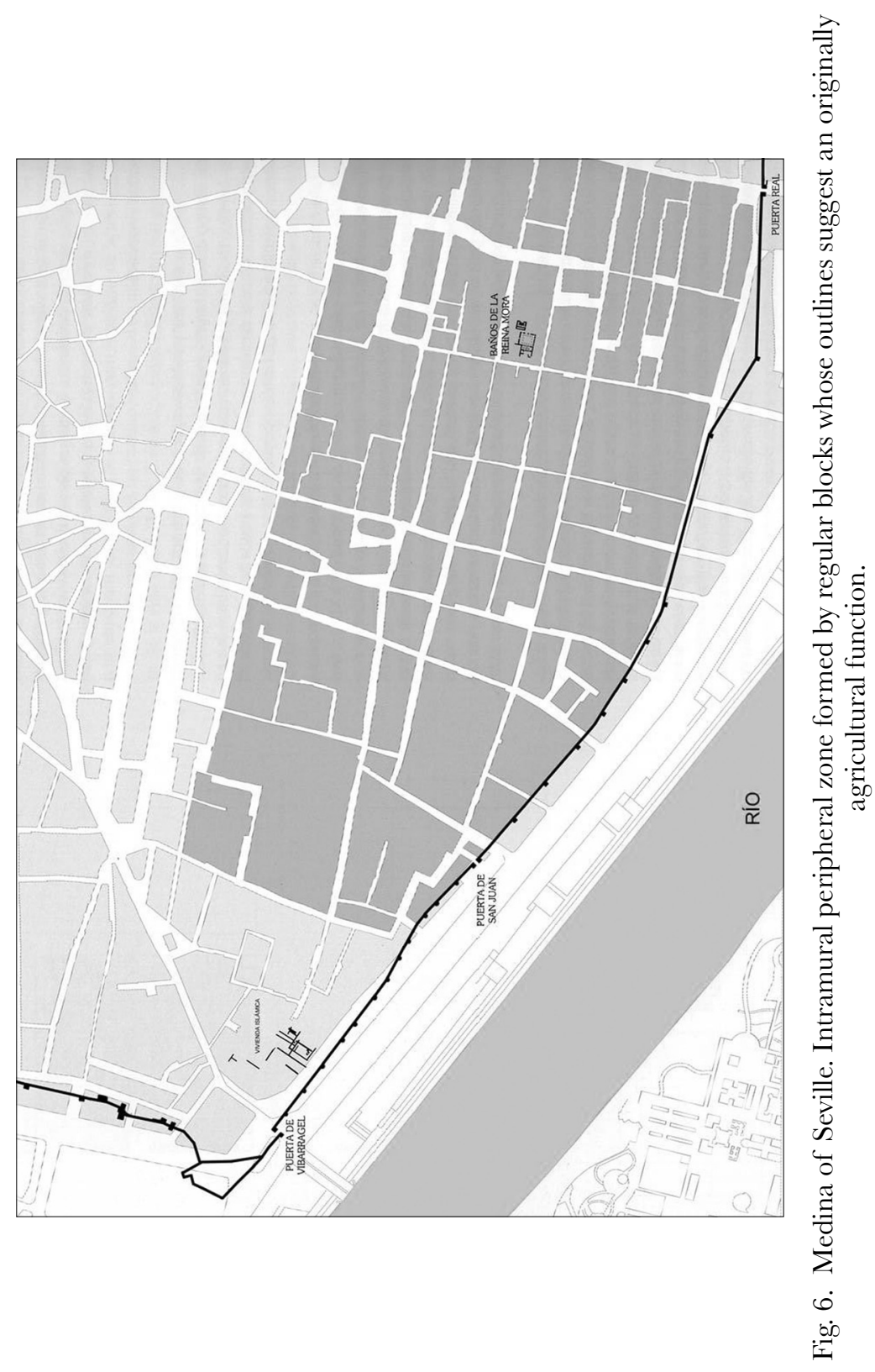




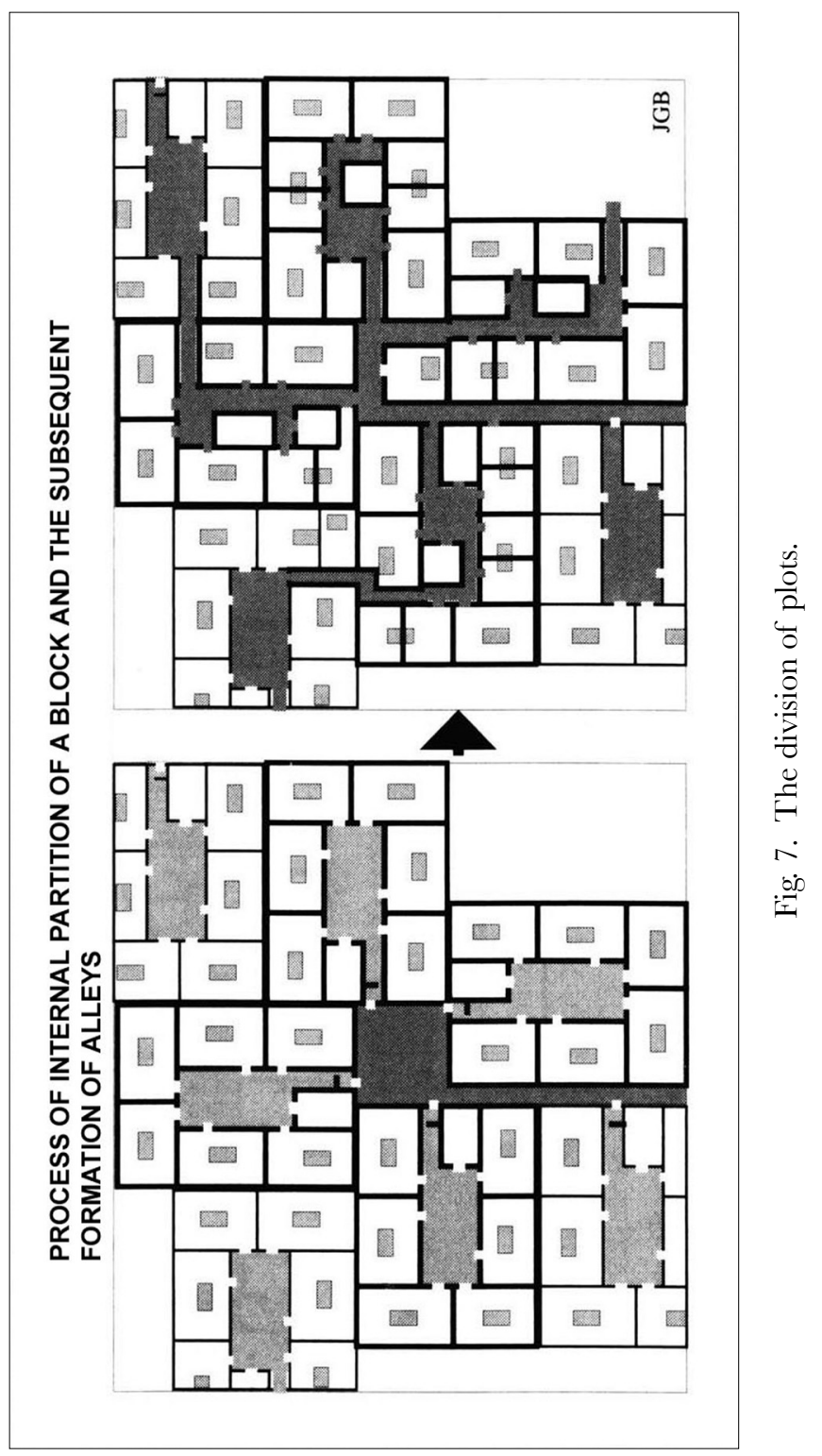


Murcia provides at least three well-documented cases. All were empty spaces which remained as such in the centre of the medina up to the twelfth century, while remains of buildings, some from the tenth century, surround them. An empty space existed within the block known as Platería 14. The space remained empty until the twelfth century, when two additional houses were built, attached to the earlier residence. ${ }^{33}$ The excavation of another early Andalusi residence carried out at Calle Zarandona, revealed an empty space south of the house, which was separated from the courtyard simply by a wall. Finally, excavations on Calle Trapería, some thirty metres from the old courtyard of the Great Mosque, revealed an unbuilt space which did not disappear until the second half of the twelfth century or the beginning of the thirteenth, when a small palace was constructed on the site. The Arabic texts confirm that during the governorship of the Almoravid 'Ali ibn Yūsuf (1106-1143) certain unbuilt sites were appropriated in order to expand the Great Mosque. ${ }^{34}$

Other examples of this process of urban densification are documented archaeologically or in the written sources: the city of Málaga and the village of Jolopos are examples of the former, while Fez is a well-known example of the latter. ${ }^{35}$ The same phenomenon is also documented in newly-formed Arab urban centres and those which developed over the last century, which have been the subjects of ethnoarchaeogical studies. ${ }^{36}$

\subsection{Building over former artisanal installations}

Certain types of artisanal establishments, namely private businesses which lacked the inherent stability of pious foundations, were easily displaced to the periphery to comply with the demand for construction space within the medina. Such expansion is reflected in the written sources, as Ibn 'Abdūn's hisha treatise indicates: "tiles and bricks must be

\footnotetext{
${ }_{33}$ Pedro Jiménez Castillo and Julio Navarro Palazón, Platería 14. Sobre cuatro casas andalusies y su evolución (siglos X-XIII) (Murcia: Ayuntamiento de Murcia, 1997), pp. 40-41.

${ }^{34}$ Alfonso Carmona González, "La expropiación forzosa por ampliación de mezquita en tres fetuas medievales", in L'urbanisme dans l'Occident musulman au Moyen Âge. Aspects juridiques, ed. Patrice Cressier et al. (Madrid: Casa de Velázquez, 2000), pp. 141-151.

${ }^{35}$ Ibn Abī Zār', Rawd al-Qirțās, translated by Ambrosio Huici Miranda (Valencia: Textos Medievales, 1964), pp. 58-95.

${ }^{36}$ See Biewers, "Occupation de l'espace"; Aurenche, "Pour une éthnoarchéologie" (details given in n. 4).
} 
manufactured outside the gates of the city, and the pottery workshops must establish themselves along the ditch which surrounds it, where there is more spacious terrain, for in the city free space is scarce". ${ }^{37}$ From this text, referring to Seville at the start of the twelfth century, we can deduce that the medina, by that period, had consumed most of the space available for construction within the walls, which until then had been used for intramural artisanal installations. ${ }^{38}$

While it is likely that the intramural potteries excavated in Murcia were originally founded outside an older enclosure and later brought into the city by the construction of new walls, archaeological evidence suggests that firm conclusions should be viewed with caution. ${ }^{39}$ For instance, excavations at a site on Calle San Nicolás in Murcia revealed a pottery workshop which, in the second half of the tenth or beginning of the eleventh century, was replaced by a large house which subsequently became a cemetery. The same process occurred in another workshop at Calle Cortés, also in Murcia (Fig. 5). It seems that, in the eleventh century, the potteries of the city's formative period were expelled outside the medina because of expansion. They were subsequently transferred to the suburb of Arrixaca, from which they were eventually removed (at least, the sites closest to the wall of the medina), due to the pressure of urban growth in the twelfth and thirteenth centuries.

Similarly, in Pechina (Almería) archaeologists have documented a zone initially dedicated to the pottery industry, which was subsequently transferred to the eastern outskirts of the town. The transfer of the industry left a space into which housing was constructed during a period of urban expansion. ${ }^{40}$ Excavations in Valencia also indicate that settlements were constructed within the ruins of older artisanal areas. Curiously, archaeologists have interpreted this as a periurban phenomenon, only brought within the city walls at the time of their construction around the eleventh century. However, such an interpretation requires the existence of an earlier wall of reduced circumference, and there is a complete lack of material evidence to support such a

\footnotetext{
37 Emilio García Gómez and Évariste Lévi-Provençal, Sevilla a comienzos del siglo XII. El tratado de hisba de Ibn Abdun (Madrid: Moneda y Crédito, 1948), p. 113.

${ }^{38}$ The study of the placement of tanneries throughout the medieval period is of great interest, since along with potteries, they serve as the most sensible indicators of the urban growth process, due to their usual location on the outskirts of the town.

${ }^{39}$ Navarro, "El cementerio islámico de San Nicolás".

${ }^{40}$ Manuel Acién Almansa et al., "Excavación de un barrio artesanal de Bayyana (Pechina, Almería)", Archéologie Islamique 1 (1990), pp. 147-168.
} 
theory. ${ }^{41}$ Again, this phenomenon is not necessarily unique to the cities of al-Andalus; in fact, the expulsion of the urban tanneries of Aleppo, Tunis and Cairo to the city outskirts during the sixteenth and seventeenth centuries, analyzed by Raymond, offers a useful parallel to the case of Valencia, despite its chronological and geographical distance from the cities of al-Andalus. ${ }^{42}$

\subsection{Cemeteries}

Cemeteries are not immune to the pressure of an expanding urban centre, as Ibn 'Abdūn indicates in his hisba treatise: "One of the most important duties of the $q \bar{a} d \bar{\imath}$ is that of demolishing the buildings that crop up within the cemetery". ${ }^{43}$ The order to demolish houses is proof of the greater resistence of cemeteries to the pressure to absorb the town, surely due to their religious character and to their status as pious foundations. The archaeological evidence indicates that, in al-Andalus, very few disappeared to make way for other uses before the thirteenth century. Usually cemeteries remained active up to the Christian conquest, the moment at which they were abandoned and subsequently built over. Of the intramural Murcian cemeteries studied to date, all were active until the conquest except for two, recently discovered and excavated, on Calle Pascual and Calle San Pedro, at the corner of Calle Desamparados (Fig. 5). The first was built over with shops, while the second was divided for houses. A third example located at Polo de Medina was partially invaded by the private bath of an adjoining house.

\section{SAturation}

This phase is characterized by a series of changes in the urban landscape that affect both private and public spaces equally: the former suffer an accelerated process of subdivision, resulting in a reduction

\footnotetext{
${ }^{41}$ Miquel Rosselló Mesquida, "Evolució i transformació de l'espai urbà des de l'època emiral fins l'època taifa: Les excavacions del c/ Comte Trènor, 12 (València)", in Actes del I Congrés d'Estudis de l'Horta Nord (Valencia: Centre d'Estudis de l'Horta Nord, 1999), pp. 57-87.

${ }^{42}$ Raymond, "Le déplacement des tanneries".

${ }^{43}$ García Gómez and Lévi-Provençal, Sevilla a comienzos del siglo XII, pp. 95 and 148.
} 
of the surface area of the built plots. The buildings erected on these plots now rise vertically, by adding rooms to the upper floors (al-ghurfa), rooms in the upper storey and with independent access (al-masriyya), or projecting rooms over the street $(s \bar{a} b \bar{a} t)$. In addition, the progressive shortage of available space to build within the medina's walls also put pressure on the public areas (streets, squares, etc.), reducing their width or making them disappear completely.

\subsection{Partitioning of houses}

When the urban fabric has expanded and become dense enough to fill its empty spaces, the ultimate result of growth without extramural expansion is the partitioning of existing houses in order to create new ones. ${ }^{44}$ The partition of old properties created the need to open new streets on private plots (al-darb or blind alley with or without a door), which give access to new dwellings located in the interior area of the blocks (Fig. 9). Exceptions to this principle exist, arising from processes of inheritance and division which have nothing to do with space shortages, and for which there is no accompanying increase in the height of the new houses. The availability of buildable surface area around existing housing sometimes enables the construction of new rooms which cluster around the old, compensating for lost surface area by creating new spaces through the process of subdivision. The phenomenon of division, part of the third phase (saturation), is also present in the proposed second phase (expansion). For example, in Siyāsa, houses ten, twelve and fourteen originally formed part of a large residence (Fig. 8); houses nine and eighteen were also the result of partitioning an even larger pre-existing residence.

Likewise, in Murcia, spacious residences, originally encompassing two or more courtyards, were subsequently transformed into individual residences. ${ }^{45}$ Scholars have interpreted this transformation as symptomatic of the breakdown of a social system based on the extended family,

\footnotetext{
${ }^{44}$ Javier García-Bellido, "Morfogénesis de la ciudad islámica: algunas cuestiones abiertas y ciertas propuestas explicativas", in L'urbanisme dans l'Occident musulman, pp. 243-283.

45 Pedro Jiménez Castillo and Julio Navarro Palazón, "Murcia omeya", in El Esplendor de los Omeyas Cordobeses. La Civilización Musulmana de Europa Occidental, ed. María Jesús Viguera Molins and Concepción Castillo (Granada: El Legado Andalusí, 2001), pp. $132-151$.
} 
but this position is difficult to sustain with the available evidence. ${ }^{46}$ Numerous examples of this process of subdivision exist, not only in Murcia but also in Pechina, Málaga, Balaguer and Mértola. ${ }^{47}$ Most recently, we analyzed a large house from the caliphal period, located on Calle Organistas in Murcia, which clearly illustrates the same phenomenon (Fig. 9). The residence consisted of a principal nucleus surrounding a courtyard of considerable dimensions, onto which opened a hall on each of its north and south sides; a small courtyard connected to the entrance hall, the latrine, and other dependencies, and service areas were situated outside the courtyard's southern hall. In the twelfth century, the residence was subdivided around its two courtyards. In order to approximate the extension of its adjacent plot, the former hall was incorporated into the southern property, creating a second house with characteristics similar to the original, but opening in the opposite direction.

\subsection{Growth in height}

An increase in the height of houses usually accompanies the process of urban saturation. Consequently, the portico-gallery comes to play an increasingly important role in this new type of vertical expansion. ${ }^{48}$ In Murcia, archaeologists have managed to document all the construction phases of excavated Andalusi buildings, providing a means of analyzing the frequency with which houses were developed through the addition of one or more stories. The archaeological data is most eloquent with respect to the late appearance of the portico-gallery, which provided access to upper rooms. In the oldest levels, this type of architectural solution was not as frequent as it came to be in Murcia during the second half of the twelfth or the first half of the thirteenth century. For example, house A of Calle Platería 14, constructed in the Almoravid

${ }^{46}$ Mariano Bernabé Guillamón and José D. López Martínez, El Palacio Islámico de la calle Fuensanta. Murcia (Murcia: Museo de Murcia, 1993), pp. 62-63.

${ }^{47}$ In Murcia, for example, the so called "palace" on Calle Fuensanta, for which see Bernabé and López, El Palacio Islámico; house number fourteen on the Calle Platería, for which see Jiménez and Navarro, Platería 14, pp. 33-39; the Garaje Villar site, for which see José Manzano Martínez, "Trabajos arqueológicos en el subsuelo de la Plaza de Europa (antiguo Garaje Villar). Ciudad de Murcia", Memorias de Arqueología 3 (1995), pp. 354-397.

${ }^{48}$ Julio Navarro Palazón and Pedro Jiménez Castillo, "Plantas altas en edificios andalusíes: la aportación de la Arqueología", Arqueología Medieval. Actas del coloquio "Formas de habitar e alimentaçâo na Idade Média” 4 (1996), pp. 107-137. 




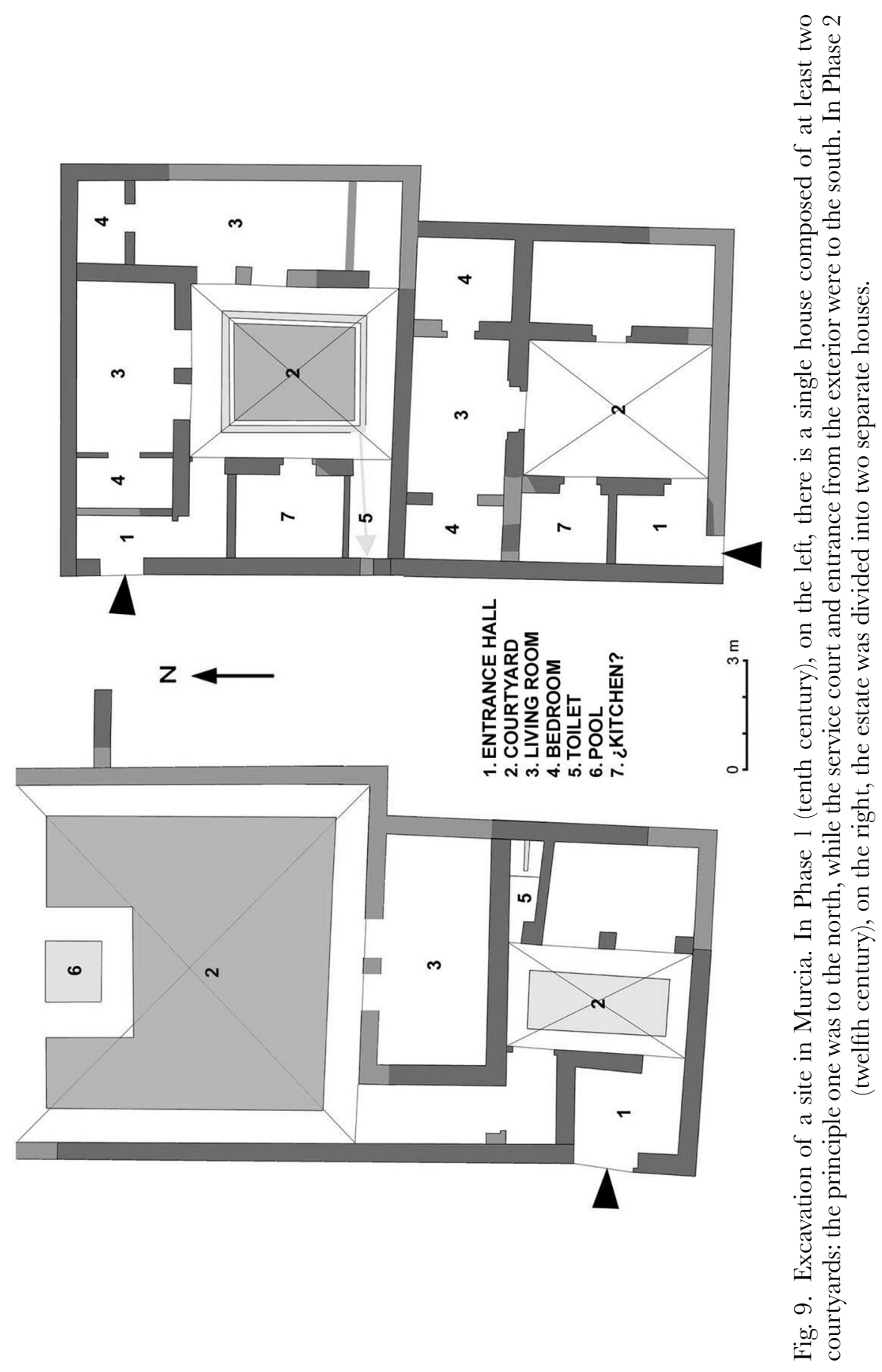


period, did not include a portico until the beginning of the thirteenth century, coinciding in date with the five-bay portico of the large house identified as Space Four in Garaje Villar. ${ }^{49}$

Lézine, in his study of the medinas of Ifrīqiyya, also believed that the construction of upper stories was a relatively late phenomenon, pointing to the testimony of the twelfth-century Valencian traveller, Ibn Jubayr, as proof. Ibn Jubayr was amazed to find that the majority of the houses in Damascus were three stories in height, for which reason, he wrote, they were able to accommodate three times the number of inhabitants as any other city. ${ }^{50}$ By the first half of the thirteenth century, upper stories were also widespread in al-Andalus, as excavations of houses, most of which had portico-galleries, at the abandoned city of Siyāsa demonstrate. In some cases, it can be shown that these were adopted at a later date: for example, house one appears to have been annexed to the older western façade of its courtyard (Fig. 8).

\subsection{Suppression or reduction of streets}

The pressure of the saturated urban centre is also evident in the public streets, which at this stage are narrowed, and in certain cases disappear as they are invaded by adjoining houses. This is a common process in traditional Islamic urbanism, resulting partly from a legal system which did not penalize the invasion of collective space in cases where there was no substantial detriment to the common good. There are abundant archaeological examples of these partial invasions by new constructions.

The first example, excavated on Calle Victorio in Murcia, consists of a regularly planned early Andalusi road measuring 2.6 metres in width. At a later phase (twelfth or thirteenth century), an adjoining building was constructed into the roadway, which lost half a metre of its width as a result. Excavations revealed a similar reduction in the width of a two and a half metre-wide alley excavated within what was once a large residence in Puxmarina (Fig. 10). One of the most important thoroughfares of Siyāsa, the road delimited by houses six and seven, likewise lost two metres to house number six, which took over some thirty centimetres of the public way (Fig. 8). In extreme cases, the street eventually disappeared completely, as has been documented

\footnotetext{
49 Jiménez and Navarro, Platería 14, pp. 30-31; Manzano, "Trabajos arqueológicos".

${ }_{50}$ Lézine, Deux villes, pp. 30-31.
} 

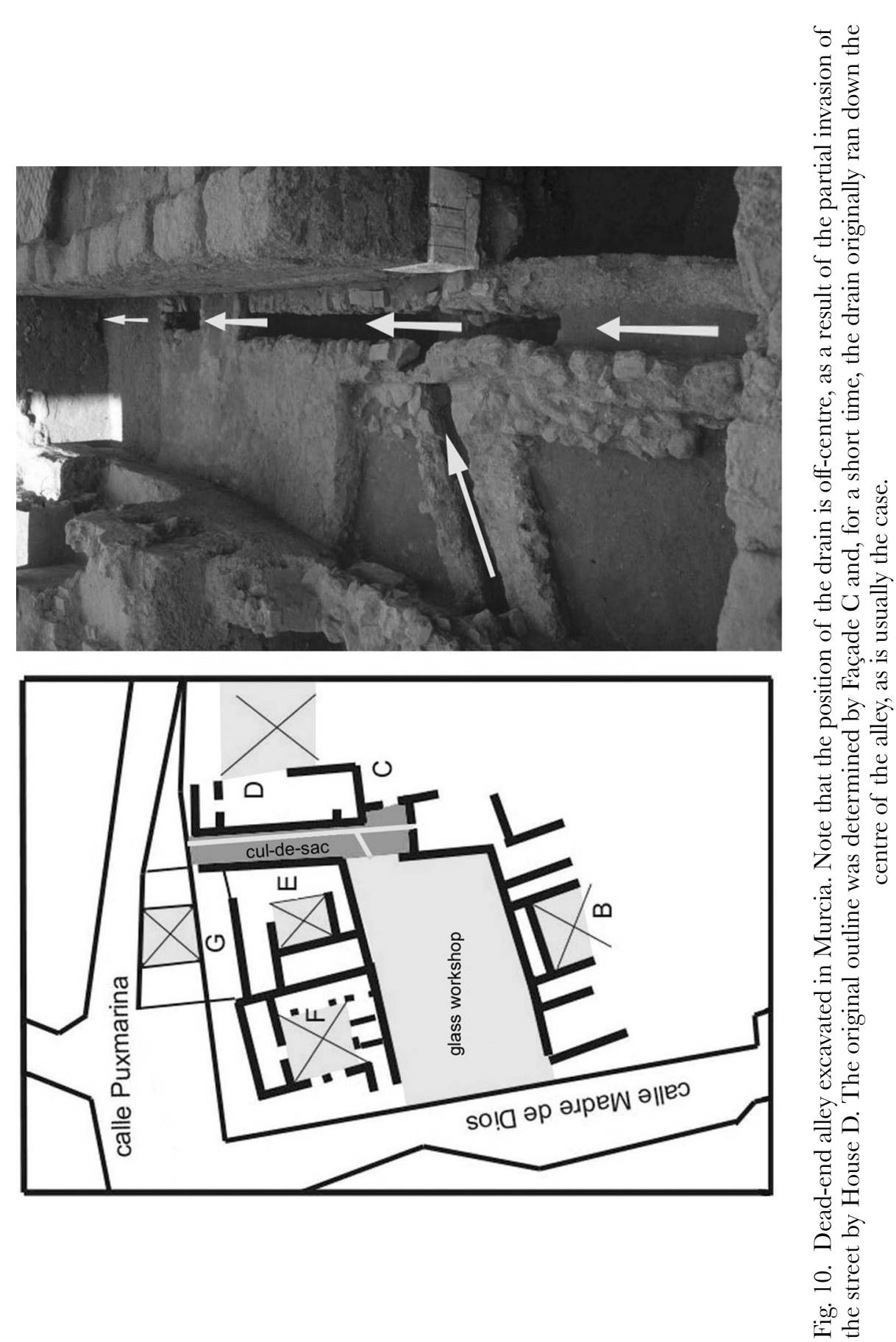
in the abandoned Toledan city of Vascos. ${ }^{51}$ Finally, the invasion of the airspace of streets and alleys through balconies and connecting passageways between facing buildings is perhaps one of the most characteristic features of the saturated phase.

\section{Overflow}

Overflow occurs when the urban centre begins to expand outside the city walls to form quarters, continuing the process which previously expelled the potteries, brickworks, tanneries, and other establishments which require a lot of space from the urban centre. The overflow phase is characterized by the presence within the new quarters of residences and other elements formerly associated with the medina proper, such as baths, markets, and neighbourhood mosques as well as congregational mosques in later periods. This overflow phenomenon, which begins along the principal roads, reached its greatest extent when the quarter was walled; at that point, the quarter had developed beyond its first stage, and initiates the same cycle that we have analyzed in the original medina: expansion, saturation, and overflow. Tenth-century Córdoba, which developed into one of the greatest cities of its time as the capital of the Umayyad state, is a relatively early example of the saturated city, while Granada is one of the best examples of the city at the overflow phase. Its particular history allowed it to continue its development until 1492, two and a half centuries after the conquest of other important urban centres of al-Andalus, like Seville, Valencia and Murcia. Nevertheless, all of these centres had evolved into overflow cities when the Castilian and Aragonese armies conquered them in the thirteenth century.

According to al-Idrīsī, in the second half of the twelfth century, Murcia possessed a walled quarter, indicating that its medina had reached the final stage of the evolutionary scheme which has been outlined here. Archaeological evidence indicates that the quarter's earth defenses were not constructed to protect the pottery workshops, cemeteries and dispersed estates (munyas), since one of the walls enclosed clearly urban elements like residential quarters, baths, mosques, markets, etc. Ample

\footnotetext{
${ }^{51}$ Ricardo Izquierdo Benito, Ciudades hispanomusulmanas "Vascos". Navalmoralejo (Toledo). Campañas 1983-1988 (Toledo: Junta de Comunidades de Castilla-La Mancha, 1994), p. 24 .
} 
unbuilt spaces of an agricultural character also extended into the zones closest to its exterior wall, with the exception of the sectors near the principal roads, Cadenas and San Antolín, which in turn developed into a compact walled centre. The green spaces, no doubt reserved for future urban expansion, would have been built up over time, but the Castilian conquest, and the consequent demographic crisis, halted the dynamic expansion of the city.

In any case, this extensive quarter was not a uniform entity in the Islamic period: all evidence indicates that the quarter's western half was occupied by a dense urban centre, while the eastern side was home to a dispersed population, characterized by broad garden zones and orchards located between those of the Alcázar Menor and other aristocratic estates. However, excavations conducted in the western half of the quarter suggest the existence of an urban landscape which had become much more saturated during the second half of the twelfth century. At this point the houses were densely packed, with no empty spaces between them. In fact, at two sites situated near Calle San Antolín, in the western sector, it is possible to detect the existence of potters' workshops which were subdivided and replaced by houses; in other words, the phenomenon of the expulsion of the pottery workshops to the periphery, which previously ocurred in the context of the medina, finally repeats itself in the quarter when it, in turn, becomes saturated. 